\title{
Cytotoxic activity in broth-culture filtrates of Campylobacter pylori
}

\author{
R. D. LEUNK*, P. T. JOHNSON, B. C. DAVID, W. G. KRAFT and D. R. MORGAN* +
}

Anti-Infective Research Department, Norwich Eaton Pharmaceuticals Inc., Norwich, New York 13815, USA

\begin{abstract}
Summary. Broth-culture filtrates of Campylobacter pylori induced non-lethal cytopathic effects in vitro in 7 of 9 mammalian cell lines tested. Transmission electronmicroscopy revealed that the response consisted of intracellular vacuolisation. Intestine 407 cells were among the most responsive and were used for routine assay. About $55 \%$ of isolates of $C$. pylori tested, originating from four geographic regions worldwide, produced cytotoxic activity. The activity was neutralisable by specific antisera to broth-culture filtrates or to sonicated bacteria but not by antisera to other bacterial preparations. Cytotoxic activity was heat-labile $\left(70^{\circ} \mathrm{C}\right.$ for $\left.30 \mathrm{~min}\right)$, was proteasesensitive and ammonium-sulphate precipitable. It did not pass through an ultrafiltration membrane with a nominal mol.-wt limit of $100 \times 10^{3}$. It was concluded that $C$. pylori can produce a factor that alters cultured cells in vitro. The relevance of this factor to the pathogenesis of gastritis associated with $C$. pylori remains to be determined.
\end{abstract}

\section{Introduction}

Campylobacter pylori is isolated from human gastric biopsy specimens, and its presence on gastric epithelium is associated with gastritis (Langenberg et al., 1984; Buck et al., 1986; Goodwin et al., 1986). Evidence is accumulating to suggest that $C$. pylori is a pathogen with an aetiologic role in gastritis rather than a harmless commensal or an invader secondary to gastritis. For example, specific antibody is often present in persons colonised by $C$. pylori and is rarely present, or present in low titres only, in uncolonised, healthy individuals (Rathbone et al., 1985; Booth et al., 1986; Jones et al., 1986). Furthermore, antimicrobial therapy of patients colonised with $C$. pylori can both eliminate the bacterium and resolve the gastric inflammation (McNulty et al., 1986). The neonatal, gnotobiotic-pig model of infection by $C$. pylori provides further evidence for its pathogenicity. Colonisation of the gastric epithelium of the piglet is accompanied by development of histological gastritis (Krakowka et al., 1987).

The histopathology of gastritis associated with

\footnotetext{
*Present address : Miami Valley Laboratories, The Procter and Gamble Co., Cincinnatti, OH, USA.

† Address for correspondence: Dr D. R. Morgan, PO Box 398707, Cincinnatti, OH 45239-8707, USA.
}

Received 2 Sep. 1987; accepted 13 Oct. 1987.
C. pylori is well characterised (Langenberg et al., 1984; Price et al., 1985; Rathbone et al., 1985; Goodwin et al., 1986; Hazell et al., 1986; Tricottet et al., 1986). Bacteria are present within the mucus layer and are associated with epithelial cells. Mucosal alterations and epithelial-cell abnormalities are noted in colonised individuals. In tissue sections, there is a high correlation between the presence of bacteria and an influx of large numbers of polymorphonuclear leucocytes. Organisms are rarely found adjacent to normal mucosa.

The mechanism by which $C$. pylori-associated gastritis develops is unknown. Specific adhesins, toxic factors and invasiveness are known among enteropathogens. Virulence determinants of $C$. pylori have not been identified. We undertook this study to determine if $C$. pylori produces any extracellular factor(s) capable of damaging cultured cells in vitro. Such a toxic factor may contribute to the pathology observed in gastric epithelial cells in the host and could contribute to the development of inflammation.

\section{Materials and methods}

\section{Cultivation of C. pylori}

All isolates of C. pylori were obtained from human gastric biopsies. They were collected from: Perth, 
Australia; Southampton, England; Lima, Peru; and Galveston, Texas and Denver, Colorado, USA. All isolates were curved gram-negative rods and possessed urease, catalase, and oxidase activities.

Isolates of $C$. pylori were routinely grown in Brucella Broth (Oxoid, Columbia, MD, USA) supplemented with fetal bovine serum $5 \% \mathrm{v} / \mathrm{v}$ (Gibco, Grand Island, NY, USA). Incubation was for $48 \mathrm{~h}$ at $37^{\circ} \mathrm{C}$ with an atmosphere of $\mathrm{CO}_{2} 10 \%, \mathrm{O}_{2} 5 \%$ and $\mathrm{N}_{2} 85 \%$ in a gyratory water bath set at $150 \mathrm{rpm}$. Cultures were harvested by centrifugation and broth-culture filtrates were prepared from culture supernates by passage through a $0.45-\mu \mathrm{m}$ filter (Gelman, Ann Arbor, MI, USA). Samples were stored at $-20^{\circ} \mathrm{C}$.

Broth-culture filtrates were concentrated by ultrafiltration on a YM-100 membrane (Amicon, Lexington, MA, USA) or by precipitation in saturated ammonium sulphate $50 \% \mathrm{v} / \mathrm{v}$. Equal parts of broth-culture filtrate and saturated ammonium sulphate were mixed at $4^{\circ} \mathrm{C}$. Precipitated material was harvested by centrifugation and resuspended in sterile phosphate-buffered saline (PBS).

In one experiment, $C$. pylori was grown in MuellerHinton Broth (BBL, Cockeysville, MD), Isosensitest Broth (Oxoid), Columbia Broth (BBL), Brain Heart Infusion Broth (Difco, Detroit, MI) with yeast extract $0 \cdot 25 \%$ (BBL), Medium 199 (Gibco) or Brucella Broth. Each base was supplemented with fetal bovine serum $10 \% \mathrm{v} / \mathrm{v}$.

\section{Cytotoxin assay procedure}

Cultured cells for use in cytotoxin assays were obtained from the American Type Culture Collection. Twentyfour-well culture plates were seeded with $2 \times 10^{4}$ cells/ well. Earle's Modified Eagles Medium with $25 \mathrm{mM}$ HEPES (Whittaker M. A. Bioproducts, Walkersville, MD) supplemented with fetal bovine serum $10 \% \mathrm{v} / \mathrm{v}, 2$ $\mathrm{mM}$ glutamine and antibiotic-antimycotic mixture (Gibco) was used for tissue culture. After $24 \mathrm{~h}$, culture medium was aspirated and $1.0 \mathrm{ml}$ of fresh medium was added per well. Test samples $(0.1 \mathrm{ml})$ were then added to the wells. After further incubation for $48 \mathrm{~h}$, cells were examined microscopically for the presence of intracellular vacuolisation and tests scored as positive if $\geqslant 50 \%$ of the cells exhibited intracellular vacuolisation.

For determination of the titre of cytotoxic activity, doubling dilutions of the test samples were made in tissue-culture medium and added to wells with cultured cells. The titre was the highest final dilution of sample that gave a positive response. A negative response was scored as 0 .

\section{Antiserum production and neutralisation of cytotoxic activity}

Three different priparations were made from a pool of 4 isolates of $C$. pylori (strains Tx30a, 133C, 60190 and 11638 ) for use as antigens. Formalinised whole cells were prepared by resuspending saline-washed bacteria to $1 \times$
$10^{9} \mathrm{cells} / \mathrm{ml}$ in formalin $0.6 \% \mathrm{v} / \mathrm{v}$ in buffered saline and stored at $4^{\circ} \mathrm{C}$. A sonicated antigen preparation was made by sonicating washed bacteria $\left(6 \times 10^{9}\right.$ cells $/ \mathrm{ml}$ of water $)$ for $5 \mathrm{~min}$ at $4^{\circ} \mathrm{C}$ in a Fisher Model 300 sonic dismembrator. Debris was removed by centrifugation at $10000 \mathrm{rpm}$ $\left(20 \mathrm{~min}\right.$ at $4^{\circ} \mathrm{C}$ ) and the supernate was passed through a $0.45-\mu \mathrm{m}$ filter. The sonicate was diluted 6-fold in sterile saline and stored at $-20^{\circ} \mathrm{C}$. A standard phenol-water extraction procedure for isolation of lipopolysaccharide was used to prepare a third antigen (Rudbach et al., 1976). The extract from $2 \times 10^{11}$ bacteria was diluted in sterile saline $(100 \mathrm{ml})$ and stored at $4^{\circ} \mathrm{C}$. A fourth antigen was prepared from a broth-culture filtrate of $C$. pylori strain $133 \mathrm{C}$. A 10 -fold concentration by ultrafiltration was followed by a $2 \cdot 5$-fold concentration by ammoniumsulphate precipitation. The precipitate was resuspended in, and dialysed against, PBS. A fifth antigen preparation was made by sonicating $C$. pylori strain $\mathrm{Tx} 30 \mathrm{a}$ (vide supra).

Male New Zealand white rabbits were immunised over a one-month period. Equal parts of antigen and Freund's complete adjuvant were emulsified and $1.0 \mathrm{ml}$ was given i.m. in each hind quarter. Subsequent immunisations were given at weekly intervals with Freund's incomplete adjuvant and antigen. Both preimmune and immune rabbit sera were prepared from blood collected by cardiac puncture.

A standard enzyme-linked immunosorbent assay (ELISA) procedure was used to titrate immune sera. Results indicated that each immune serum had an ELISA titre of $\geqslant 32000$ for the corresponding immunogen. Titres of pre-immune sera were $\leqslant 100$.

To test for neutralisation of cytotoxic activity, preimmune or immune sera were pre-diluted in PBS. Brothculture filtrate was concentrated 10 -fold by ultrafiltration or ammonium-sulphate precipitation. Equal parts of prediluted serum and concentrated filtrate were mixed and incubated for $60 \mathrm{~min}$ at $37^{\circ} \mathrm{C}$. The mixture $(0 \cdot 2 \mathrm{ml})$ was then used in the standard cytotoxin assay. The neutralisation titre of an antiserum was the highest dilution capable of complete neutralisation of cytotoxic activity.

\section{Electronmicroscopy}

Cell cultures were fixed in situ for $60 \mathrm{~min}$ at room temperature in glutaraldehyde $2 \% \mathrm{v} / \mathrm{v}$ in $0.1 \mathrm{M}$ sodium-

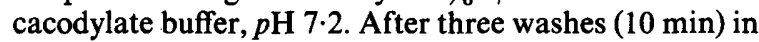
buffer, cells were post-fixed for $1 \mathrm{~h}$ at room temperature in $\mathrm{O}_{\mathrm{s}} \mathrm{O}_{4} 2 \% \mathrm{v} / \mathrm{v}$ in distilled water and washed twice (10 min) in distilled water. Dehydration was in a graded series of ethanol. Cells were embedded in the culture plate in Medcast.

Ultrathin sections were stained with uranyl acetate and lead citrate and examined with a JEOL 1200 electronmicroscope at $80 \mathrm{kV}$.

\section{Biological activity of culture filtrates}

Broth-culture filtrates of $C$. pylori were tested for activity in a standard rabbit ileal-loop assay (Evans et al., 
1973) and suckling-mouse assay (Gianella, 1976). Escherichia coli strains MOON, DBEC and ATCC 25922 were used as positive controls for heat-stable, heat-labile and non-toxic activities, respectively.

\section{Other reagents}

Urea Agar Base Concentrate (BBL) was diluted 10fold in distilled water for use in determination of urease activity. Urease purified from jack bean (type IX) or from Bacillus pasteurii (type $\mathrm{X}$ ) were purchased from Sigma, St Louis, MO, USA. Trypsin $(2.5 \% \mathrm{w} / \mathrm{v})$ was from Gibco and proteinase K (type XI) was from Sigma.

\section{Results}

\section{Identification of cytotoxic activity}

Several cultured mammalian cell lines were used to screen for cytotoxic activity produced by $C$. pylori. Some cell lines were included because they were originally derived from the gastrointestinal tract, others because they are known to be responsive to bacterial toxins in vitro. Initial screening revealed that some broth-culture filtrates of $C$. pylori induced alterations in appearance of some of the cell lines. Broth-culture filtrates of two isolates of C. pylori, or supplemented Brucella broth as a negative control, were then concentrated 15 -fold by ammonium sulphate precipitation. The titre of cytotoxic activity of these preparations for the nine cell lines was compared (table I). Intestine 407 and $\mathrm{HeLa}$ cells were the most responsive, exhibiting cytopathic effects at sample dilutions of $\geqslant 320$. HEp-2, WiDR, 5637, Vero cells and KATO III were also responsive but to a lesser degree. Y-1 and CHO-K1 cells were relatively unresponsive and did not exhibit cytopathic effects under conditions in which other cell lines did. Intestine 407 cells were used routinely for the other experiments.

For each of the responsive cell lines, the cell response consisted of intracellular vacuolisation (fig. 1). Phase-contrast microscopy revealed that the cell cytoplasm was filled with large vacuoles. Transmission electronmicroscopy confirmed that the vacuoles were membrane bound, containing an electron lucent reticular material with some small membranous inclusions (fig. 2). Other ultrastructural abnormalities were not observed.

The cytopathic response was present as early as $24 \mathrm{~h}$ after addition of the broth-culture filtrate of $C$. pyloriand was maximal by $48 \mathrm{~h}$. Even after exposure to broth-culture filtrate for one week, Intestine 407 cells could exclude Trypan Blue though they remained highly vacuolated.

\section{Production of cytotoxic activity}

Numerous isolates of $C$. pylori from geographically diverse sources were screened for production of cytotoxic activity. Titres of cytotoxic activity in broth-culture filtrates were relatively low (table II). Precipitation of broth-culture filtrates with ammonium sulphate gave quantitative concentration of cytotoxic activity, as evidenced by substantially increased titres. In some cases, concentration of broth-culture filtrate enabled detection of cytotoxic activity that had not been detectable before concentration.

Table I. Responsiveness of different cell lines to cytotoxic activity in concentrated broth-culture filtrates of C.pylori

\begin{tabular}{|c|c|c|c|}
\hline \multirow[b]{2}{*}{ Cell line } & \multirow[b]{2}{*}{ Cell type } & \multicolumn{2}{|c|}{$\begin{array}{l}\text { Titre of cytotoxic activity with } \\
{ }^{*} \text { filtrate from } C \text {. pylori }\end{array}$} \\
\hline & & $\begin{array}{l}\text { strain } \\
60190\end{array}$ & $\begin{array}{l}\text { strain } \\
26695\end{array}$ \\
\hline Intestine 407 & Human embryonic intestine; HeLa markers & $\geqslant 320$ & 80 \\
\hline HeLa & Human epitheloid cervical carcinoma & $\geqslant 320$ & 80 \\
\hline HEp-2 & Human larynx epidermoid carcinoma; HeLa markers & 160 & 40 \\
\hline WiDR & Human colon adenocarcinoma & 160 & 20 \\
\hline 5637 & Human bladder primary carcinoma & 80 & 20 \\
\hline Vero & African green monkey kidney & 80 & 10 \\
\hline KATO III & Human gastric adenocarcinoma & 40 & 40 \\
\hline$Y-1$ & Mouse adrenal tumour & 20 & 0 \\
\hline CHO-K1 & Chinese hamster ovary & 20 & 0 \\
\hline
\end{tabular}

* Samples were concentrated 15 -fold by ammonium-sulphate precipitation; none of the cell lines was reactive in control tests with culture medium. 

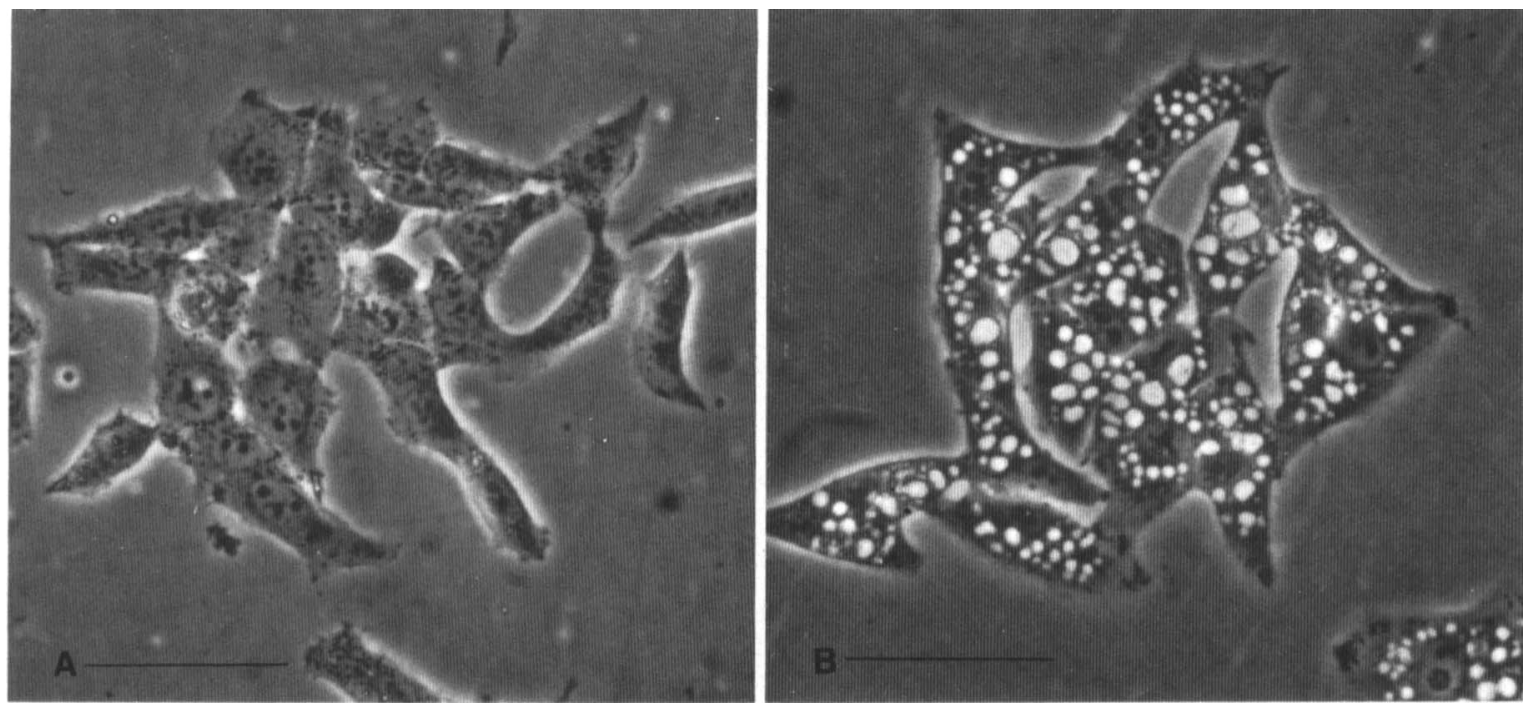

Fig. 1. Phase micrographs of Intestine 407 cells incubated for $48 \mathrm{~h}$ in the presence of concentrated Brucella Broth (A) and brothculture filtrate of $C$. pylori (B) and showing, respectively, the normal appearance and intracellular vacuolisation. Bar marker represents $10 \mu \mathrm{m}$.

A total of 201 isolates of $C$. pylori from four worldwide geographic regions was surveyed for production of cytotoxic activity (table III). Brothculture filtrates were concentrated by ammoniumsulphate precipitation for screening. Overall, 55\% of the isolates tested produced the cytotoxic activity including isolates from all four geographic regions.

Six different bacterial-culture media were compared for their ability to modulate production of cytotoxic activity by $C$. pylori. The bacterium was

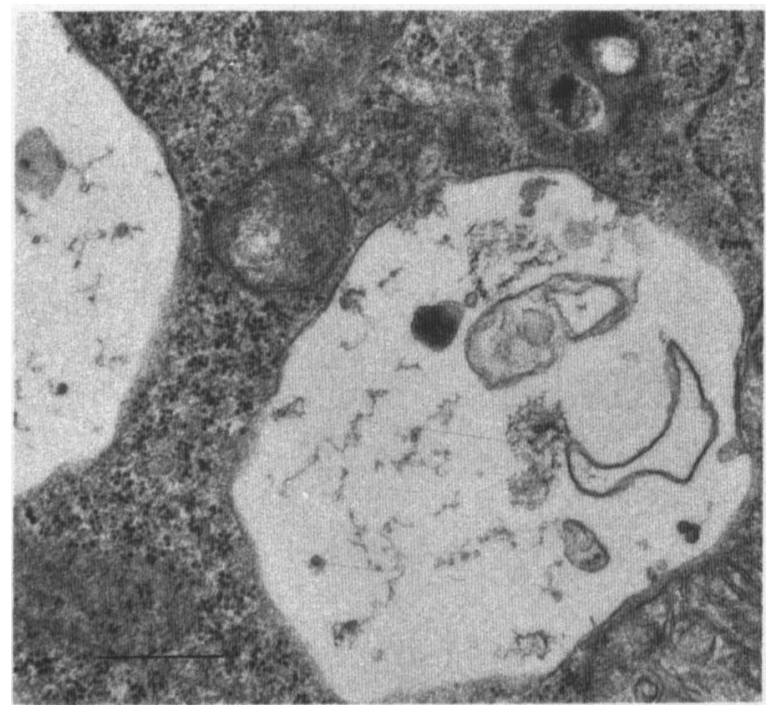

Fig. 2. Transmission electronmicrograph of membrane-bound vacuole of Intestine 407 cells induced by broth-culture filtrate of C. pylori. Bar marker represents $1 \mu \mathrm{m}$.
Table II. Ammonium-sulphate precipitation of cytotoxic activity from broth culture filtrates of C. pylori

\begin{tabular}{l|cc}
\hline Strain & $\begin{array}{c}\text { Titre of cytotoxic activity of filtrate } \\
\text { before and after precipitation* }\end{array}$ \\
\hline $133 C$ & 20 & $\geqslant 320$ \\
60190 & 20 & $\geqslant 320$ \\
$100 C$ & 10 & 80 \\
11638 & 0 & 40 \\
Tx100 & 0 & 10 \\
Pu3 & 0 & 0 \\
Tx30a & 0 & 0 \\
\hline
\end{tabular}

* See footnotes, table I.

grown in Brucella Broth, Mueller-Hinton Broth, Isosensitest Broth, Columbia Broth, Brain Heart Infusion Broth with yeast extract or in Medium 199. Cytotoxic activity was produced equally in all media except Medium 199 in which decreased growth of $C$. pylori correlated with decreased cytotoxic activity. No culture medium was able to induce production of cytotoxic activity in an isolate from which it was not detected when grown in Brucella broth.

Sonicates of isolates of $C$. pylori that produced cytotoxic activity in their broth-culture filtrates could also induce intracellular vacuolisation if prepared from suspensions containing $\geqslant 1 \times 10^{10}$ bacteria/ml. The titres of cytotoxic activity in sonicates of $C$. pylori were generally low, ranging from 20 to 80 . 
Table III. Production of cytotoxic activity by isolates of C. pylori

\begin{tabular}{lc}
\hline Source & $\begin{array}{c}\text { Number of isolates producing } \\
\text { cytotoxic activity/number tested }\end{array}$ \\
\hline Australia & $2 / 2$ \\
England & $5 / 11$ \\
Peru & $96 / 179$ \\
USA & $7 / 9$ \\
All & $110 / 201$ \\
\hline
\end{tabular}

\section{Neutralisation of cytotoxic activity with specific antiserum}

Several different anti- $C$. pylori sera were tested for ability to neutralise cytotoxic activity in brothculture filtrates of $C$. pylori (table IV). Three of the rabbit antisera were prepared against different preparations of a pool of four isolates of C. pylori, three of which produced cytotoxic activity. The anti-formalinised whole-cell serum and the antisonicated-cell serum both neutralised cytotoxic activity. The antiserum prepared against a phenolwater extract did not neutralise despite its high titre to both homologous antigen and to whole-cell isolates of C. pylori. Rabbit antiserum to a concentrated broth-culture filtrate preparation from an isolate (strain 133C) producing cytotoxic activity also neutralised cytotoxic activity. Rabbit antiserum to the sonicate of an isolate of $C$. pylori from which cytotoxic activity could not be detected (strain Tx30a) did not neutralise cytotoxic activity.
For all of the above, neutralisation gave a reduction in titre of cytotoxic activity from 80-320 to 0 .

Neutralising antisera were able to inhibit cytotoxic activity in broth-culture filtrates of all three isolates of $C$. pylori tested, whether or not that particular isolate was included in the antigen used for immunisation. Furthermore, neutralising antiserum prepared against the broth-culture filtrate of $C$. pylori could also abrogate the ability of sonicates of $C$. pylori to induce intracellular vacuolisation.

\section{Characterisation of cytotoxic activity}

Heat stability and enzyme sensitivity of the cytotoxic activity were studied (table V). Cytotoxic activity was stable to heating at $56^{\circ} \mathrm{C}$ for $30 \mathrm{~min}$ but was completely destroyed by heating at $70^{\circ} \mathrm{C}$ for $30 \mathrm{~min}$. Incubation of broth-culture filtrates with either trypsin or proteinase $K(0.001 \% \mathrm{w} / \mathrm{v})$ also abolished cytotoxic activity. Broth-culture filtrate of C. pylori was concentrated by ultrafiltration on a membrane with an exclusion limit of mol. wt $100 \times 10^{3}$ (table V). Cytotoxic activity was recovered almost quantitatively from the retentate. The filtrate did not possess ability to induce intracellular vacuolisation. Cytotoxic activity of broth-culture filtrates was non-dialysable with dialysis tubing the pore size of which retained material of mol. wt $50 \times 10^{3}$ (table V).

Other bacteria, including strains of $E$. coli, Aeromonas hydrophila, Shigella sonnei, Proteus spp., $C$. jejuni and $C$. fetus, were grown as described for $C$. pylori. No broth-culture filtrate of any of these

Table IV. Neutralisation of cytotoxic activity of $C$. pylori by specific antiserum

\begin{tabular}{|c|c|c|c|c|}
\hline Antiserum prepared against & Status & $\begin{array}{l}\text { Titre in } \\
\text { ELISA test* }\end{array}$ & $\begin{array}{l}\text { Neutralising } \\
\text { ability } \dagger\end{array}$ & $\begin{array}{c}\text { Neutralising } \\
\text { titre }+\end{array}$ \\
\hline Formalinised, whole cells of pooled strains & $\begin{array}{l}\text { Pre-immune } \\
\text { Immune }\end{array}$ & $\begin{array}{r}<1000 \\
6400\end{array}$ & $\overline{-}$ & 16 \\
\hline Sonicate of cells of pooled strains & $\begin{array}{l}\text { Pre-immune } \\
\text { Immune }\end{array}$ & $\begin{array}{l}<1000 \\
128000\end{array}$ & $\overline{-}$ & 8 \\
\hline Phenol-water extract of pooled strains & $\begin{array}{l}\text { Pre-immune } \\
\text { Immune }\end{array}$ & $\begin{array}{r}<1000 \\
32000\end{array}$ & $\begin{array}{l}- \\
-\end{array}$ & 0 \\
\hline Broth-culture filtrate of strain $133 \mathrm{C}$ & $\begin{array}{l}\text { Pre-immune } \\
\text { Immune }\end{array}$ & $\begin{array}{r}2000 \\
64000\end{array}$ & $\overline{+}$ & 8 \\
\hline Sonicate of strain $\mathrm{T} \times 30 \mathrm{a}$ & $\begin{array}{l}\text { Pre-immune } \\
\text { Immune }\end{array}$ & $\begin{array}{r}1000 \\
128000\end{array}$ & - & 0 \\
\hline
\end{tabular}

\footnotetext{
* Highest dilution of serum reacting with whole $C$. pylori by ELISA.

$\dagger$ Neutralising ability was: + , present; - , absent in tests performed as described in Materials and methods.

$\ddagger$ Highest dilution of immune serum completely neutralising cytotoxic activity.
} 
Table V. Characterisation of cytotoxic activity in broth-culture filtrate of $C$. pylori

\begin{tabular}{lc}
\hline Treatment & Cytotoxic activity* \\
\hline Heat: & + \\
$56^{\circ} \mathrm{C}$ for $30 \mathrm{~min}$ & - \\
$70^{\circ} \mathrm{C}$ for $30 \mathrm{~min}$ & - \\
Enzyme: & - \\
trypsin $\dagger$ \\
proteinase $\mathrm{K}$ & + \\
none & \\
Ultrafiltration: & + \\
retentate \\
filtrate \\
$\begin{array}{l}\text { Dialysis: } \\
\text { retentate } \\
\text { dialysate }\end{array}$ \\
None & - \\
\hline
\end{tabular}

* Cytotoxic activity was: +, present; -, absent.

$\dagger$ Enzyme treatments, including no-enzyme control, were at $37^{\circ} \mathrm{C}$ for $60 \mathrm{~min}$.

$\ddagger$ The nominal mol.-wt limits $\left(10^{3}\right)$ of the ultrafiltration membrane and the dialysis tubing were, respectively, 100 and 50.

bacteria induced intracellular vacuolisation. In certain cases, e.g., with $E$. coli and $A$. hydrophila, known bacterial toxins were identified. Cytotoxic effects induced by these toxins, however, did not appear similar to those induced by preparations of C.pylori.

All broth-culture filtrates of $C$. pylori, unconcentrated or concentrated by ultrafiltration or ammonium-sulphate precipitation, were unreactive when tested in two standard assays for bacterial enterotoxins. Appropriate control strains of $E$. coli, however, reacted positively in these assays.

Consideration was given to the possibility that the extremely large amount of urease produced by C. pylori (Langenberg et al., 1984; McNulty and Wise, 1985) might be responsible for the cytotoxic activity. Broth-culture filtrates of $C$. pylori did not contain urease activity as measured by their inability to give a positive urease reaction in $24 \mathrm{~h}$ in a liquid urease-test medium. Furthermore, urease purified from the jack bean or from $B$. pasteurii did not induce intracellular vacuolisation at concentrations up to 3500 and $1800 \mu \mathrm{M}$, respectively.

\section{Discussion}

A cytotoxic, though not cytolethal, factor was identified in broth-culture filtrates of $C$. pylori. This factor was capable of inducing intracellular vacuolisation in 7 of 9 cultured mammalian cell lines tested. HeLa cells, and two other cell lines with HeLa markers (Intestine 407 and HEp-2), were the most responsive. The appearance and nature of the cytotoxic effect and the pattern of cell responsiveness are unlike the in-vitro cellular responses to known bacterial toxins. This characteristic cell response to broth filtrates of $C$. pylori was not reproduced by similarly prepared broth-culture filtrates of several other bacterial species. In addition, broth-culture filtrate preparations of $C$. pylori were inactive in the rabbit ileal-loop and suckling-mouse assays. Together, these data suggest that the cytotoxic factor of $C$. pylori may be novel among bacterial toxins.

Production of cytotoxic activity was widespread among isolates of $C$. pylori. Of the isolates tested, $55 \%$ produced cytotoxic activity and this included isolates from all geographic regions. Most isolates tested had been frequently passaged in vitro. Loss of cytotoxin production upon laboratory passage may be one explanation for the inability of some isolates to produce cytotoxic activity. Though it was not directly studied, inconsistent cytotoxin production was noted for only one isolate during the experimentalperiod.

The titre of cytotoxic activity in broth-culture filtrates of $C$. pylori was generally low. For some isolates, concentration of broth-culture filtrate was required to detect production of cytotoxic activity. Again, different isolates of $C$. pylori produced different levels of cytotoxic activity. The level of cytotoxic activity (as indicated by the titre) did not correlate with the viable numbers of bacteria in cultures, suggesting that only small amounts of the cytotoxic factor are produced or that the cytotoxin assay is fairly insensitive.

Specific antiserum to a crude toxin preparation neutralised cytotoxic activity as did an antiserum to the sonicate of pooled isolates. Antiserum to the sonicate of one isolate of $C$. pylori from which cytotoxic activity was not detected was nonneutralising. These data suggest that the cytotoxic effects observed are specifically induced by a bacterial product, rather than the result of a nonspecific alteration in the environment of the cultured cells. The finding that the phenol-water extract of the four pooled isolates did not raise a neutralising antiserum suggested that the cytotoxic factor was absent from this antigen preparation. Indeed, a standard dye-binding protein assay (BioRad, Rockville Centre, NY) revealed that the phenol-water extract antigen-preparation contained only trace amounts of protein.

The heat-lability and protease-sensitivity of cytotoxic activity suggest that the factor is protein- 
aceous and the observations with an ultrafiltration membrane suggest that the cytotoxic factor may be a molecule or complex of high mol. wt.

It seemed unlikely that the cytotoxic response was due to the urease of $C$. pylori because all isolates possessed high levels of urease yet only some strains produced cytotoxic activity. Furthermore, purified plant or bacterial ureases and broth-culture filtrates of other urease-producing bacteria did not reproduce the cytotoxic effects.

Johnson and Lior (1986) reported the production by $C$. pylori of two factors which were active against mammalian cells in vitro and they identified a cytotoxic activity for $\mathrm{CHO}$ cells in polymyxin-B lysates of $C$. pylori. Furthermore, a cytotonic factor, capable of inducing elongation of CHO cells and present in culture filtrates, was identified. Whereas these investigators grew $C$. pylori in a bi-phasic culture system, it was grown in broth in our study; thus, comparison of results is difficult. Because cytotoxic effects were manifested in different ways in the two studies, viz., elongation of $\mathrm{CHO}$ cells and vacuolisation of Intestine 407 cells, it is possible that there is more than one cytotoxic factor.

The significance of intracellular vacuolisation as

\section{REFERENCES}

Booth L et al. 1986 Clinical importance of Campylobacter pyloridis and associated serum $\operatorname{IgG}$ and $\operatorname{IgA}$ antibody responses in patients undergoing upper gastrointestinal endoscopy. Journal of Clinical Pathology 39: 215-219.

Buck G E, Gourley W G, Lee W K, Subramanyam K, Latimer J M, DiNuzzo A R 1986 Relation of Campylobacter pyloridis to gastritis and peptic ulcer. Journal of Infectious Diseases 153: 664-669.

Evans D G, Evans D J, Pierce N F 1973 Differences in the response of rabbit small intestine to heat-labile and heatstabile enterotoxins of Escherichia coli. Infection and Immunity 7: 873-880.

Gianella R A 1976 Suckling mouse model for detection of heatstable Escherichia coli enterotoxin: characteristics of the model. Infection and Immunity 14: 95-99.

Goodwin C S, Armstrong J A, Marshall B J 1986 Campylobacter pyloridis, gastritis, and peptic ulceration. Journal of Clinical Pathology 39: 353-365.

Hazell S L, Lee A, Brady L, Hennessy W 1986 Campylobacter pyloridis and gastritis: association with intracellular spaces and adaptation to an environment of mucus as important factors in colonization of the gastric epithelium. Journal of Infectious Diseases 153: 658-663.

Johnson W M, Lior H 1986 Production of heat-labile cytotoxin by Campylobacter pyloridis. Abstracts of the Annual Meeting of the American Society for Microbiology, 1986, Abstract no. B 234 .

Jones D M, Eldridge J, Fox A J, Sethi P, Whorwell P J 1986 Antibody to the gastric Campylobacter-like organism (Cam- the observed cytotoxic effect is not clear because that may be a general indicator of cell degeneration. On the other hand, $i \hat{i}$ may be the result of a cellular process specifically triggered by a bacterial product. Concentrated broth-culture filtrates did not cause death but it is possible that exposure to higher, or repeated, doses of broth-culture filtrate of $C$. pylori-or even to a purified factor-might do so.

It is interesting that intracellular vacuolisation has been observed by electronmicroscopy in gastric epithelial cells from patients with chronic gastritis (Tricottet et al., 1986). Whether the cytotoxic activity produced by $C$. pylori in vitro is also produced in vivo is not known. The close association of $C$. pylori with the gastric epithelial surface could allow for effective delivery to epithelial cells of a cytotoxic factor, even one that is produced in low amounts. Nonetheless, the role of this cytotoxic activity in the development of gastritis should be evaluated in the host.

We gratefully acknowledge the skilled technical assistance of Mr R. Bush and Ms D. McCarthy with animal immunisations and ELISA assays and thank Mr A. Crooker and $\mathrm{Mr}$ T. Beard for electronmicroscopy.

pylobacter pyloridis) - clinical correlations and distribution in the normal population. Journal of Medical Microbiology 22: $57-62$.

Krakowka S, Morgan D R, Kraft W G, Leunk R D 1987 Establishment of gastric Campylobacter pylori infection in the neonatal gnotobiotic piglet. Infection and Immunity 55: 2789-2796.

Langenberg M L, Tytgat G N J, Schipper M E I, Rietra P J G M, Zangen H C 1984 Campylobacter-like organisms in the stomach of patients and healthy individuals. Lancet 1, 1348-1349.

McNulty C A M et al. 1986 Campylobacter pyloridis and associated gastritis: investigator blind, placebo controlled trial of bismuth salicylate and erythromycin ethylsuccinate. British Medical Journal 293: 645-649.

McNulty C A M, Wise R 1985 Rapid diagnosis of Campylobacterassociated gastritis. Lancet 1: 1443-1444.

Price A B et al. 1985 Campylobacter pyloridis in peptic ulcer disease: microbiology, pathology, and scanning electron microscopy. Gut 26: 1183-1188.

Rathbone B J, Wyatt J I, Worsley B W, Trejdosiewicz L K, Heatley R V, Losowsky M S 1985 Immune response to Campylobacter pyloridis. Lancet 1 : 1217.

Rudbach J A et al. 1976 Preparation and properties of a national reference endotoxin. Journal of Clinical Microbiology 3: 2125.

Tricottet V et al. 1986 Campylobacter-like organisms and surface epithelium abnormalities in active, chronic gastritis in humans: an ultrastructural study. Ultrastructural Pathology 10: $113-122$. 
